\title{
Impact of Marjoram (Origanum marjorana L.) Essential Oil on Some Virulence Factors and DNA Integrity of Multidrug Resistant Klebsiella pneumoniae
}

\author{
El-Tablawy, S. Y ${ }^{1}$ and Araby, E. ${ }^{2}$ \\ ${ }^{I}$ Drug Radiation Research Department, \\ ${ }^{2}$ Radiation Microbiology Department National Center for Radiation Research and Technology (NCRRT), \\ Atomic Energy Authority (AEA), P.O. Box 29, Nasr City, Cairo, Egypt
}

\begin{abstract}
Infectious diseases represent an important cause of morbidity and mortality among the populations, particularly in developing countries. Therefore, pharmaceutical companies have been motivated to develop new antimicrobial drugs in the recent years especially due to the constant emergence of microorganisms resistant to conventional antimicrobials. The current study aims to evaluate the antimicrobial efficacy of some essential oils (EOs) against multidrug resistant (MDR) K. pneumoniae. Antibiotic susceptibility profile of $15 \mathrm{~K}$. pneumoniae isolates was performed against 14 antibiotics and 14 essential oils. The effect of the most potent EO against the chosen isolate regarding some virulence factors and DNA fragmentation was studied. Among all the tested antibacterial agents, MEO was the most effective one. Gas chromatography/mass spectrometry of MEO revealed that, terpinen-4-ol was the major constituent followed by $\gamma$-terpinene. Treatment using MEO led to a significant reduction in biofilm formation, complete killing within 4 hours, change in membrane permeability and reduction of capsular layer of the tested cells. Also, 2 MIC of MEO caused the highest damage of bacterial DNA. This study strongly suggests that MEO possesses antibacterial properties and induces DNA degradation. These results were correlated with chemical composition of the tested oil.
\end{abstract}

Key Words; Antimicrobial resistance; Essential oils; Biofilm formation; DNA fragmentationn

\section{Introduction}

Drug-resistant microbes can spread among people and animals, from one country to another-without a notice. From the early stages of identifying and discovering antibiotic resistance, the problem was clearly severe in developing countries where drug availability was limited and resistance was high. Klebsiella pneumoniae bacteria are a group of an emerging highly drug-resistant Gram-negative bacilli causing infections associated with significant morbidity and mortality whose incidence are rapidly increasing in a variety of clinical settings around the world. ${ }^{1}$

K. pneumoniae includes numerous mechanisms for antibiotic resistance. Treatment of infections caused by Klebsiella is increasingly problematic because of its resistance to a growing number of antibiotics including $\beta$-lactamases due to its ability to grow as a biofilm. ${ }^{2,3}$ The challenge presented by biofilm infections is revealed in the remarkable resistance to both host immune responses and available chemotherapeutics. ${ }^{4}$

Medicinal plants have been used as a source of many medications that are now applied in clinical practice. The use of herbal extracts as antimicrobial agents shows a low risk of increasing resistance to their action, because they are complex mixtures, this makes microbial adaptability very difficult. It is also reported that the herbal extracts have minimal side effects. ${ }^{5,6}$ According to the World Health Organization (WHO) more than $80 \%$ of the world population relies on traditional medicine for their primary health care needs. ${ }^{7}$

Essential oils are natural, volatile liquids, complex compounds characterized by a strong odor, rarely colored, soluble in lipid and organic solvents. They could be synthesized by all plant organs. ${ }^{8}$ Essential oils generally have 2-3 major components at fairly high concentrations (20-70\%) compared to other components present in trace amount. Varieties of essential oils have been screened for their antimicrobial activity. The antimicrobial activity of plant-derived essential oils is the basis of diverse applications, especially in food preservation, aromatherapy and medicine. Approximately 3,000 essential oils are currently known so far. Out of which, 300 are commercially important and widely used in the pharmaceutical, agronomic, food, sanitary, cosmetic and perfume industries. ${ }^{9}$

Hence, the current study was undertaken to investigate the antibacterial activity of different essential oils against 15 clinical isolates of $K$. pneumoniae compared to reference antibiotics. The effect of the most potent essential oil (EO) on some of the virulence factors of highly sensitive isolates such as biofilm formation, capsule expression, rate of kill and cell membrane permeability as well as DNA degradation was elucidated. 


\section{Bacterial isolates \& cultivation media}

\section{Materials and Methods}

Fifteen different clinical isolates of K. pneumoniae were obtained from Drug Microbiology Laboratory, Drug Radiation Research Department at the NCRRT. They were maintained on Nutrient agar, NA (Oxoid). The tested isolates were cultivated in a standard laboratory culture media. Tryptone Glucose Yeast Extract Agar (TGY); Nutrient agar (NA), Brain Heart Infusion agar (BHI) were purchased from Difco [Difco Labs, Detroit, Michigan (USA)]. Tryptic Soy broth (TSB) and Muller Hinton Agar (MHA) were obtained from Oxoid (Oxoid. comp., Basigstoke, Hants,UK)].

\section{Essential oils}

Fourteen medicinal plants; Jojoba, Juniper, Cypress, Ginseng, Thymus, Amla, Parsley, Mustard, Colocynth, Ginger, Salvia, Marjoram, Coriander and Rosemary were used. The parts of plants (90 g, in triplicates) were separately subjected to hydrodistillation for $4 \mathrm{~h}$. using a Clevenger-type apparatus to produce essential oils. The oils were dried over anhydrous sodium sulphate and the essential oils obtained were stored at $4{ }^{\circ} \mathrm{C}$ in dark- sealed vials to prevent light-sensitive decomposition.

\section{Antibiotic resistance profile}

All K. pneumoniae isolates were tested for their susceptibilities to antibiotics using the disc diffusion agar method ${ }^{\mathbf{1 0}}$ in accordance with Clinical and Laboratory Standard Institute recommendations. ${ }^{11}$ The following antimicrobial disks ( $\mu \mathrm{g}$ ) (Oxoid) were used: amikacin (AK30), ticarcillin (75) + clavulanic acid (TIM 85), sulphamxhexzol- trimethoprim (SXT25), chloramphenicol (C30), azithromycin (AZ 15), amoxicillin (AML 25), tobramycin (TOB 10), colistin sulphate (CT 25), cefepime (FEP 30), ceftazidine (CAZ 30), nitrofurantoin (F30), imipenem (IPM10), norfloxacin (NOR10), and ciprofloxacin (Cipro5).

\section{Antibacterial activity assay}

The antibacterial activity assay was carried out using the disc diffusion method. ${ }^{\mathbf{1 2}}$ Briefly, filter paper discs (Whatman No.1, $6 \mathrm{~mm}$ diameter) containing $20 \mu \mathrm{l}$ of the selected essential oils were applied to the surface of agar plates that were previously seeded by spreading of $0.1 \mathrm{ml}$ (containing $1 \times 10^{6} \mathrm{cfu} / \mathrm{ml}$ ) from overnight culture. All the plates were incubated at $37^{\circ} \mathrm{C}$ for $24 \mathrm{~h}$. The experiment was performed in triplicates. The antimicrobial activity was determined by measuring the diameter of inhibition zone $(\mathrm{mm})$ and the mean values were calculated.

\section{Determination of the minimal inhibitory concentrations (MICs) and minimal bactericidal concentration (MBCs)}

MICs and MBCs of the most effective oil against the MDR isolates were determined. ${ }^{13}$ Different concentrations of the oil ranged from 2.5 to $100 \mu \mathrm{l} / \mathrm{ml}$ were inoculated in agar plates ( $9 \mathrm{~cm}$ in diameter) and in each plate, $0.1 \mathrm{ml}$ of microbial suspensions of the selected isolate was spread on the surface and incubated at $37^{\circ} \mathrm{C}$ for $24 \mathrm{~h}$. MIC was defined as the lowest concentration of the tested oil which inhibited the microbial growth after $24 \mathrm{~h}$. MBC was defined as the lowest concentration yielding no growth following incubation at $37^{\circ} \mathrm{C}$ for $48 \mathrm{~h}$. Data from at least three replicates were evaluated and averages were calculated.

\section{Gas Chromatography-mass spectrometry (GC-MS) analysis}

The GC-MS analysis of the essential oil from marjoram (Origanum marjorana L.) sample was performed on a Hewlett-Packard model 6890 series, GC System equipped with a HP 5973 MS detector (EI mode, $70 \mathrm{eV}$ ). A column type HP-5 (5\% phenyl dimethylsiloxane) with a length of $30 \mathrm{~m}$, an inside diameter of $0.25 \mathrm{~mm}$ and a film thickness of $0.25 \mu \mathrm{m}$, was used. The temperature of the column was programmed to increase after $5 \mathrm{~min}$ from 70 to $150^{\circ} \mathrm{C}$ at the rate of $2^{\circ} \mathrm{C} / \mathrm{min}$ and then after other $5 \mathrm{~min}$ from 150 to $250^{\circ} \mathrm{C}$ at the rate of $1^{\circ} \mathrm{C} / \mathrm{min}$. Helium was used as a carrier gas at a flow rate of $1 \mathrm{ml} / \mathrm{min}$. The injector and detector temperatures were 250 and $280^{\circ} \mathrm{C}$, respectively. The components in the oil sample under investigation was identified on the basis of gas chromatographic retention indices, mass spectra from Wiley MS Chemstation Libraries $\left(6^{\text {th }}\right.$ ed., $\mathrm{G}$ 1034, Rev.C.00.00, Hewlett-Packard, Palo Alto, CA). ${ }^{\mathbf{1 4}}$

\section{Qualitative determination of slime production}

The qualitative determination of slime was described by Freeman et al. ${ }^{15}$ The composition of medium (CRA) was BHI 37g/L, Sucrose 50g/L, agar $10 \mathrm{~g} / \mathrm{L}$ and Congo red $0.8 \mathrm{~g} / \mathrm{L}$. Congo red stain was prepared as a concentrated aqueous solution and autoclaved separately at $121^{\circ} \mathrm{C}$ for $15 \mathrm{~min}$. It was added when the agar had cooled to $55^{\circ} \mathrm{C}$. Plates were inoculated and incubated aerobically at $37^{\circ} \mathrm{C}$ for $24 \mathrm{~h}$. Isolates that produced black colonies with dry crystalline consistency were regarded as slime positive, whereas those showing pink colonies were slime negative. 


\section{Quantitative determination of slime production}

Biofilm production was determined by using a spectrophotometric method. ${ }^{16}$ Stationery $18 \mathrm{~h}$. culture of the tested bacterial isolates in $5 \mathrm{ml}$ of TSB were washed, diluted with fresh medium and standardized to contain about $\left(10^{5} \mathrm{cfu} / \mathrm{ml}\right)$. Aliquots of $0.2 \mathrm{ml}$ of the diluted cultures were added to the wells of sterile flat-bottom polystyrene tissue culture plates. After incubation for $48 \mathrm{~h}$ at $37^{\circ} \mathrm{C}$, the contents of the tissue culture plates were gently aspirated with a micropipette. The plates were then washed with sterile buffer. Slime and adherent materials were fixed by incubating them for $1 \mathrm{~h}$ at $60{ }^{\circ} \mathrm{C}$ and then staining them with crystal violet (1\%) for $5 \mathrm{~min}$. After washing with water to remove the excess stain, the plates were dried for $30 \mathrm{~min}$ at $37{ }^{\circ} \mathrm{C}$, then the optical densities (ODs) of isolates adherent biofilms have been read using Microplate Reader-SunoStick SPR$960 \mathrm{~B}$, at $595 \mathrm{~nm}$. Adherence measurements were performed in quadruplicate and repeated in triplicate. ${ }^{17}$

\section{The anti-biofilm activity of the tested oil}

The anti-biofilm activity of MEO was evaluated through testing its ability to prevent the bacterial adherence using spectrophotometric method as follows: In each well of tissue culture plate $150 \mu 1$ of $18 \mathrm{~h}$. broth culture of the applied isolate and $50 \mu 1$ of MEO were mixed, in case of control, $50 \mu 1$ of sterile buffer was used and completed as previously mentioned.

\section{Time- kill assay}

A time- kill assay was used to investigate the bactericidal activity of (MEO) against $K$. pneumoniae isolate no.3. It was performed according to Klepser $\boldsymbol{e t}$ al. ${ }^{\mathbf{1 8}}$ the selected isolate was grown in Muller Hinton agar (MHA) for $24 \mathrm{~h}$. prior to testing. Colonies derived from a culture in MHA were suspended in $0.9 \% \mathrm{NaCl}$, subsequently, $0.5 \mathrm{ml}$ of the bacterial suspension $\left(1 \times 10^{8} \mathrm{cfu} / \mathrm{ml}\right)$ was added to $4.5 \mathrm{ml} \mathrm{MH}$ broth with or without MEO in various appropriate concentrations (1/4MIC, 1/2 MIC, MIC and 2MIC). These cultures were incubated at $37{ }^{\circ} \mathrm{C}$ for different time periods $(0,2,4,6,8,10$ and $12 \mathrm{~h}$.). Aliquot $100 \mu \mathrm{l}$ of each dilution was removed and placed in plates with $\mathrm{MH}$ agar. Plates were incubated at $37^{\circ} \mathrm{C}$ for $24-48 \mathrm{~h}$., and colonies were counted. The $\log _{10}$ $\mathrm{cfu} / \mathrm{ml}$ were plotted against time to check the rate and extent of antibacterial activity in various MEO concentrations.

\section{Effect of MIC of MEO on membrane permeability (Crystal violet assay)}

The alteration in membrane permeability was detected by crystal violet assay. ${ }^{19}$ Briefly, suspensions of the selected isolate were prepared in BHI broth. Cells were harvested at $4500 \mathrm{xg}$ for $5 \mathrm{~min}$ at $4^{\circ} \mathrm{C}$. The cells were washed twice and re-suspended in phosphate buffered saline (PBS) at $\mathrm{pH}$ 7.4. MEO was added to the cell suspensions and incubated for $30 \mathrm{~min}$ at $37^{\circ} \mathrm{C}$. The cells were harvested by centrifugation at $4500 \mathrm{xg}$ for $5 \mathrm{~min}$. Then, the cells were re-suspended in PBS containing $0.01 \mathrm{mg}$ of crystal violet. The cell suspension was then incubated for $10 \mathrm{~min}$ at $37^{\circ} \mathrm{C}$ and centrifuged at $4500 \mathrm{xg}$ for $2 \mathrm{~h}$., and then $\mathrm{OD}_{590}$ of the supernatants were measured. (All tests were conducted in triplicates).

\section{Effect of MEO on the bacterial capsule}

The effect of MIC level of MEO on the bacterial capsule was detected according to Finegold and Barton. ${ }^{20}$ MIC was added to bacterial suspension $\left(10^{6} \mathrm{cfu} / \mathrm{ml}\right)$, samples (control and treated) were incubated for $24 \mathrm{~h}$ at $37^{\circ} \mathrm{C}$, the presence of capsule was revealed using the Anthony's capsular staining method. Bacterial suspension was mixed with a loopful of skimmed milk on a glass slide; the smear was dried, stained with $1 \%$ aqueous crystal violet for 2 min and rinsed with a solution of $20 \%$ copper sulphate. The capsule is unstained against a purple background; the cells are deeply stained under an oil immersion lens at optical microscope.

\section{DNA fragmentation assay}

The ability of MEO to cause DNA fragmentation for the tested $K$. pneumoniae was detected. ${ }^{21}{ }^{1 / 2}$ MIC, MIC and 2MIC for the tested oil was added to $10 \mathrm{ml} \mathrm{LB}$ broth containing $K$. pneumoniae $\left(10^{5} \mathrm{cell} / \mathrm{s} / \mathrm{ml}\right)$ and was incubated at $32^{\circ} \mathrm{C}$ with $150 \mathrm{rpm}$ shaking. One $\mathrm{ml}$ of each MEO-bacteria combination was withdrawn and submitted to centrifugation for $15 \mathrm{~min}$ at $6000 \mathrm{rpm}$ followed by DNA extraction ${ }^{22}$. For control, genomic DNA was isolated from $K$. pneumoniae that was cultured without MEO. The extracted DNA was checked for fragmentation using gel documentation system.

\section{Statistical analysis}

Data were analyzed by unpaired two-tailed student's t-test ${ }^{23}$.The difference between means was considered to be statistically significant at $(\mathrm{p}<0.05)$. 


\section{Results}

In this study, the antibiotic susceptibility patterns of the 15 clinical isolates of $K$. pneumoniae to 14 different antibiotics were carried out .The results are summarized in Table (1). The results indicate that the tested isolates showed a high level of resistance. The most effective antibiotics were IPM [66.6\%] followed by AZM and C [60\%, 46.7\%], respectively. FEP, F, NOR, CIP affects [20\%] of the tested isolates, while SXT and CT affect [13.3\%]. Finally AML affects [6.7\%] for the tested isolates. While they were resistant to AK, TIM, TOB and CAZ.

Table 1 In-vitro antimicrobial susceptibilities for the collected $K$. pneumoniae clinical isolates to 14 antibiotics

\begin{tabular}{|l|l|l|l|l|l|l|l|l|l|l|l|l|l|l|}
\hline $\begin{array}{l}\text { Antibiotics } \\
\text { Isolates }\end{array}$ & AK & TIM & SXT & C & AZM & AML & TOB & CT & FEP & CAZ & F & IPM & NOR & CIP \\
\hline $\boldsymbol{K}_{\boldsymbol{l}}$ & $\mathrm{R}$ & $\mathrm{R}$ & $\mathrm{I}$ & $\mathrm{I}$ & $\mathrm{R}$ & $\mathrm{R}$ & $\mathrm{R}$ & $\mathrm{S}$ & $\mathrm{I}$ & $\mathrm{R}$ & $\mathrm{I}$ & $\mathrm{R}$ & $\mathrm{R}$ & $\mathrm{R}$ \\
\hline $\boldsymbol{K}_{2}$ & $\mathrm{R}$ & $\mathrm{R}$ & $\mathrm{R}$ & $\mathrm{S}$ & $\mathrm{S}$ & $\mathrm{R}$ & $\mathrm{R}$ & $\mathrm{R}$ & $\mathrm{R}$ & $\mathrm{R}$ & $\mathrm{R}$ & $\mathrm{S}$ & $\mathrm{R}$ & $\mathrm{R}$ \\
\hline $\boldsymbol{K}_{3}$ & $\mathrm{R}$ & $\mathrm{R}$ & $\mathrm{R}$ & $\mathrm{R}$ & $\mathrm{R}$ & $\mathrm{R}$ & $\mathrm{R}$ & $\mathrm{R}$ & $\mathrm{R}$ & $\mathrm{R}$ & $\mathrm{R}$ & $\mathrm{R}$ & $\mathrm{R}$ & $\mathrm{R}$ \\
\hline $\boldsymbol{K}_{4}$ & $\mathrm{R}$ & $\mathrm{R}$ & $\mathrm{R}$ & $\mathrm{R}$ & $\mathrm{I}$ & $\mathrm{R}$ & $\mathrm{R}$ & $\mathrm{R}$ & $\mathrm{S}$ & $\mathrm{R}$ & $\mathrm{R}$ & $\mathrm{S}$ & $\mathrm{S}$ & $\mathrm{R}$ \\
\hline $\boldsymbol{K}_{5}$ & $\mathrm{R}$ & $\mathrm{R}$ & $\mathrm{R}$ & $\mathrm{R}$ & $\mathrm{R}$ & $\mathrm{R}$ & $\mathrm{R}$ & $\mathrm{R}$ & $\mathrm{R}$ & $\mathrm{R}$ & $\mathrm{R}$ & $\mathrm{R}$ & $\mathrm{R}$ & $\mathrm{I}$ \\
\hline $\boldsymbol{K}_{\boldsymbol{6}}$ & $\mathrm{R}$ & $\mathrm{R}$ & $\mathrm{R}$ & $\mathrm{R}$ & $\mathrm{S}$ & $\mathrm{S}$ & $\mathrm{R}$ & $\mathrm{R}$ & $\mathrm{R}$ & $\mathrm{R}$ & $\mathrm{R}$ & $\mathrm{S}$ & $\mathrm{R}$ & $\mathrm{R}$ \\
\hline $\boldsymbol{K}_{7}$ & $\mathrm{R}$ & $\mathrm{R}$ & $\mathrm{R}$ & $\mathrm{I}$ & $\mathrm{R}$ & $\mathrm{R}$ & $\mathrm{R}$ & $\mathrm{R}$ & $\mathrm{R}$ & $\mathrm{R}$ & $\mathrm{S}$ & $\mathrm{I}$ & $\mathrm{R}$ & $\mathrm{R}$ \\
\hline $\boldsymbol{K}_{\boldsymbol{8}}$ & $\mathrm{R}$ & $\mathrm{R}$ & $\mathrm{R}$ & $\mathrm{I}$ & $\mathrm{R}$ & $\mathrm{R}$ & $\mathrm{R}$ & $\mathrm{R}$ & $\mathrm{R}$ & $\mathrm{R}$ & $\mathrm{S}$ & $\mathrm{S}$ & $\mathrm{S}$ & $\mathrm{R}$ \\
\hline $\boldsymbol{K}_{9}$ & $\mathrm{R}$ & $\mathrm{R}$ & $\mathrm{R}$ & $\mathrm{R}$ & $\mathrm{I}$ & $\mathrm{R}$ & $\mathrm{R}$ & $\mathrm{R}$ & $\mathrm{R}$ & $\mathrm{R}$ & $\mathrm{R}$ & $\mathrm{I}$ & $\mathrm{R}$ & $\mathrm{R}$ \\
\hline $\boldsymbol{K}_{10}$ & $\mathrm{R}$ & $\mathrm{R}$ & $\mathrm{I}$ & $\mathrm{I}$ & $\mathrm{I}$ & $\mathrm{R}$ & $\mathrm{R}$ & $\mathrm{R}$ & $\mathrm{R}$ & $\mathrm{R}$ & $\mathrm{R}$ & $\mathrm{I}$ & $\mathrm{R}$ & $\mathrm{R}$ \\
\hline $\boldsymbol{K}_{11}$ & $\mathrm{R}$ & $\mathrm{R}$ & $\mathrm{R}$ & $\mathrm{R}$ & $\mathrm{I}$ & $\mathrm{R}$ & $\mathrm{R}$ & $\mathrm{R}$ & $\mathrm{R}$ & $\mathrm{R}$ & $\mathrm{R}$ & $\mathrm{R}$ & $\mathrm{R}$ & $\mathrm{R}$ \\
\hline $\boldsymbol{K}_{12}$ & $\mathrm{R}$ & $\mathrm{R}$ & $\mathrm{R}$ & $\mathrm{S}$ & $\mathrm{S}$ & $\mathrm{R}$ & $\mathrm{R}$ & $\mathrm{R}$ & $\mathrm{R}$ & $\mathrm{R}$ & $\mathrm{R}$ & $\mathrm{S}$ & $\mathrm{R}$ & $\mathrm{R}$ \\
\hline $\boldsymbol{K}_{13}$ & $\mathrm{R}$ & $\mathrm{R}$ & $\mathrm{R}$ & $\mathrm{R}$ & $\mathrm{S}$ & $\mathrm{R}$ & $\mathrm{R}$ & $\mathrm{S}$ & $\mathrm{R}$ & $\mathrm{R}$ & $\mathrm{R}$ & $\mathrm{S}$ & $\mathrm{S}$ & $\mathrm{I}$ \\
\hline $\boldsymbol{K}_{14}$ & $\mathrm{R}$ & $\mathrm{R}$ & $\mathrm{R}$ & $\mathrm{I}$ & $\mathrm{R}$ & $\mathrm{R}$ & $\mathrm{R}$ & $\mathrm{R}$ & $\mathrm{R}$ & $\mathrm{R}$ & $\mathrm{R}$ & $\mathrm{I}$ & $\mathrm{R}$ & $\mathrm{I}$ \\
\hline $\boldsymbol{K}_{15}$ & $\mathrm{R}$ & $\mathrm{R}$ & $\mathrm{R}$ & $\mathrm{R}$ & $\mathrm{I}$ & $\mathrm{R}$ & $\mathrm{R}$ & $\mathrm{R}$ & $\mathrm{I}$ & $\mathrm{R}$ & $\mathrm{R}$ & $\mathrm{R}$ & $\mathrm{R}$ & $\mathrm{R}$ \\
\hline
\end{tabular}

amikacin (AK), ticarcillin (75) + clavulanic acid (TIM), sulphamxhexzol- trimethoprim (SXT), chloramphenicol (C), azithromycin (AZ), amoxicillin (AML), tobramycin (TOB), colistin sulphate (CT), cefepime (FEP), ceftazidine (CAZ), nitrofurantoin (F), imipenem (IPM), norfloxacin (NOR), and ciprofloxacin (Cipro).

Table 2 shows the antibacterial activity of 14 essential oils (previously mentioned) against the highly MDR $K$. pneumoniae (named $K_{3}, K_{5}, K_{9}, K_{11}, K_{14}$ and $K_{15}$ ). The results demonstrated that EOs exhibited different levels of antibacterial activities against the assayed $K$. pneumoniae isolates, the data clearly indicated that the most potent EO was marjoram (MEO) which highly affected all the tested isolates (100\%) followed by coriander and rosemary oils. However, the tested bacteria showed a variation in their susceptibility for MEO. MICs of MEO were determined for the selected isolates, the MICs ranged from 5 to $25 \mu \mathrm{l} / \mathrm{ml}$ as shown in table (3).

Table 2 Antibacterial activity for some $\mathrm{EO}_{\mathrm{s}}$ against the MDR K. pneumoniae

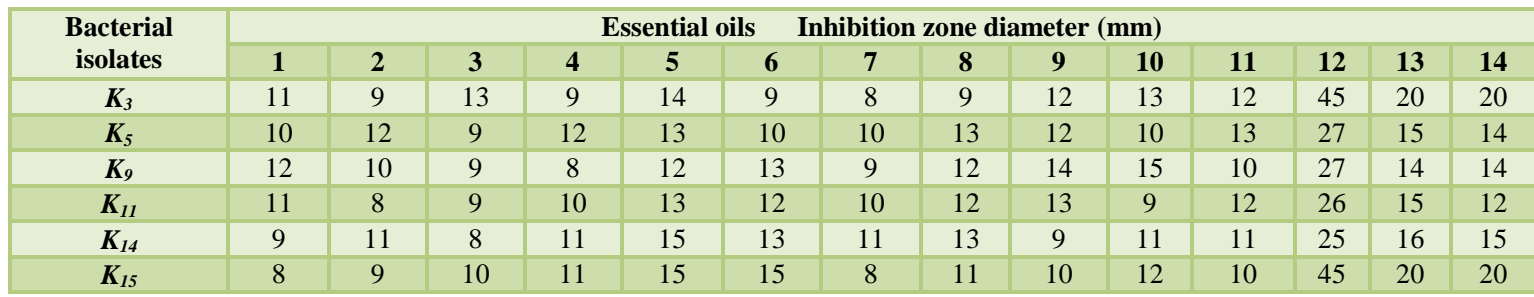

1-Jojoba, 2-Juniper, 3-Cypress, 4- Ginseng, 5- Thymus, 6- Amla, 7- Parsley, 8- Mustard, 9- Colocynth, 10- Ginger, 11- Salvia, 12Marjoram, 13-Coriander, and 14- Rosemary. According to Krivoshein 1989 ${ }^{\mathbf{2 4}}$. <10 mm stable, 10-15 mm weakly sensitive, $15-25 \mathrm{~mm}$ moderately sensitive, $>25 \mathrm{~mm}$ highly sensitive

Table $3 \mathrm{MIC}_{\mathrm{s}}$ and $\mathrm{MBC}_{\mathrm{s}}$ of $\mathrm{MEO}$ against the tested $K$. pneumoniae

\begin{tabular}{|l|r|r|}
\hline Tested isolates & MIC & MBC \\
\hline $\boldsymbol{K}_{\mathbf{3}}$ & 5 & 5 \\
\hline $\boldsymbol{K}_{\mathbf{5}}$ & 25 & 25 \\
\hline $\boldsymbol{K}_{\boldsymbol{9}}$ & 25 & 25 \\
\hline $\boldsymbol{K}_{11}$ & 25 & 25 \\
\hline $\boldsymbol{K}_{14}$ & 25 & 25 \\
\hline $\boldsymbol{K}_{15}$ & 7.5 & 10 \\
\hline
\end{tabular}

Analysis of the MEO using GC/MS resulted in fractionated and identified of 24 components in the MEO (table 4), the main components of the MEO were Terpinen-4-ol (27.34\%), $\gamma$-terpinene (18.37\%) and Linalool 
(14.49) followed by Sabinene (9.59 \%), $\alpha$ - terpinene $(8.47 \%)$, Cis-sabinene hydrate $(6.5 \%)$ and trans- sabinene hydrate (3.9\%). GC/Mass analysis, also, revealed that some compounds are presented in MEO in appreciable amounts such as Thymol (2.84\%), Linalyl acetate (1.6\%) and limonene (1.36\%). On the other hand, there are many constituents of the MEO were traced (i.e.) less than 1\%, while unknown components represented $1.44 \%$.

Table 4. Chemical constituents of MEO by GC/Mass

\begin{tabular}{|c|c|c|}
\hline Components & Rt/min & Percentage \\
\hline $\boldsymbol{\beta}$-caryophyllene & 11.748 & 0.26 \\
\hline $\boldsymbol{\beta}$-pinene & 12.052 & 0.64 \\
\hline $\boldsymbol{\alpha}$ - terpinene & 5.204 & 8.47 \\
\hline p-cymene & 8.403 & 0.31 \\
\hline Cis-sabinene hydrate & 7.345 & 6.50 \\
\hline Terpinen-4-ol & 8.768 & 27.34 \\
\hline $\boldsymbol{\gamma}$-terpinene & 14.717 & 18.37 \\
\hline Thymol methyle ether & 15.349 & 0.71 \\
\hline Linalyl acetate & 15.641 & 1.60 \\
\hline $\boldsymbol{\beta}$-Elemene & 16.078 & 0.29 \\
\hline Sabinene & 17.027 & 9.59 \\
\hline $\boldsymbol{\gamma}$-terpinol & 10.605 & 0.29 \\
\hline Isoterpinolene & 11.031 & 3.90 \\
\hline Thymol & 5.338 & 0.64 \\
\hline Limonene & 8.476 & 2.84 \\
\hline Linalool & 11.687 & 1.36 \\
\hline $\boldsymbol{\alpha}$-terpinyl acetate & 6.603 & 14.49 \\
\hline Carvacol & 11.858 & 0.15 \\
\hline Estragole & 12.150 & 0.50 \\
\hline Myrcene & 12.575 & 0.01 \\
\hline acetic acid & 12.916 & 0.08 \\
\hline $\boldsymbol{\alpha}$-Humulene & 14.911 & 0.05 \\
\hline Unknown & 17.988 & 0.02 \\
\hline indenol & 20.00 & 0.01 \\
\hline & 20.923 & 1.44 \\
\hline
\end{tabular}

Rt, retention time in min.

Biofilm formation has an important role in the pathogenesis of $K$. pneumoniae. Therefore, isolates under this study were tested for their ability to produce biofilm. It was found that all of them showed a dry black crystalline morphology indicating strong biofilm formation. The changes in the biofilm formation after treatment with MICs of MEO were evaluated quantitatively. The data shown in Fig. 1 indicated that MICs of MEO caused a reduction of 3 fold or more in the $\mathrm{OD}_{595}$ reading compared to the control with a significant change ( $p$-value $<0.005$ ). Except in case of $K_{14 \text {, the }}$ change is not significant ( $p$-value $=0.0647$ ). Interestingly, the tested isolates still strongly produce biofilms, except for $\mathrm{K}_{3}$ where it becomes weakly adherent with a significant p-value (0.0005).

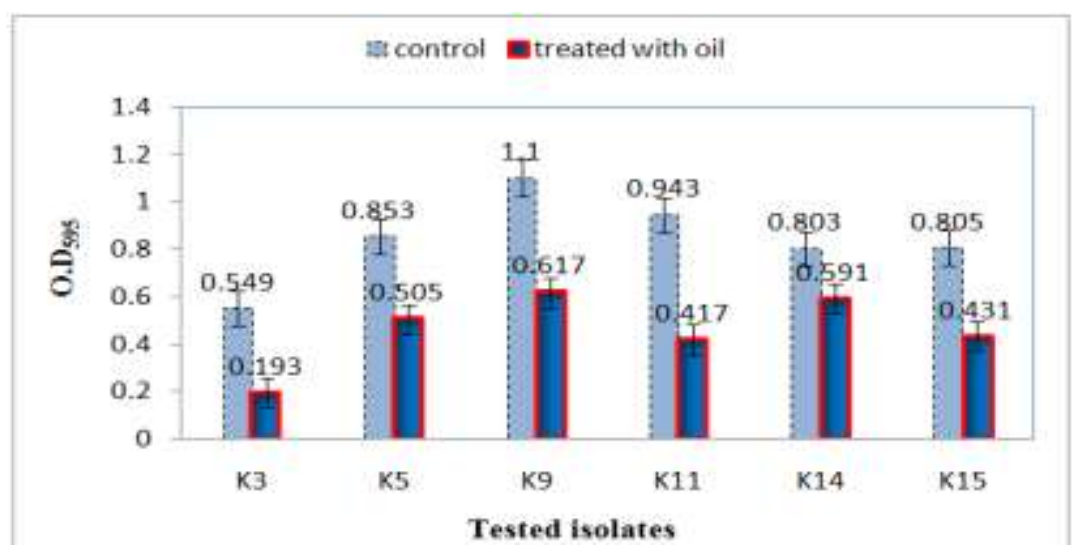

Fig. 1. The anti-biofilm activity of MICs of MEO against the tested isolates

$\mathrm{OD} \leq 0.120$ : Non-adherent, $0.120<\mathrm{OD} \leq 0.240$ : Weakly adherent, $\mathrm{OD}>0.24$ : Strongly adherent. according to Christensen et al. ${ }^{16}$ 
The results revealed that $\mathrm{K}_{3}$ was the most MDR isolate and it showed a high susceptibility to MEO (MIC 5 $\mu 1 / \mathrm{mL}$ ). Also, MEO variously affects its biofilm production from strong to weak. So, $\mathrm{K}_{3}$ was chosen for further studies. Fig. 2 demonstrated that, increased concentrations of $\mathrm{MEO}$ against $\mathrm{K}_{3}$ caused increase killing of $K 3$ cells. $2 \mathrm{MIC}$ and MIC of MEO caused complete killing within 4 and 6 hours, respectively. While 1/2 MIC treatment caused a complete killing after $8 \mathrm{~h}$ indicating that the effect of EO is bactericidal.

Alterations in permeability were assessed by the uptake of crystal violet dye. Fig. 3 showed that the treatment using different concentrations results in significant permeability changes when compared to the control (p-value < 0.005). MIC and 2MIC affect significantly cell membrane permeability p-value (0.0001). The effect of MIC of MEO on capsule expression of $K_{3}$ isolate was investigated under light microscope. As shown in Fig. (4A), the outer surface of the control cells is seen to be covered with a thick layer of capsule surrounding the cell, while fig. (4B) showed a reduction in the capsular layer with deformation of the treated cell.

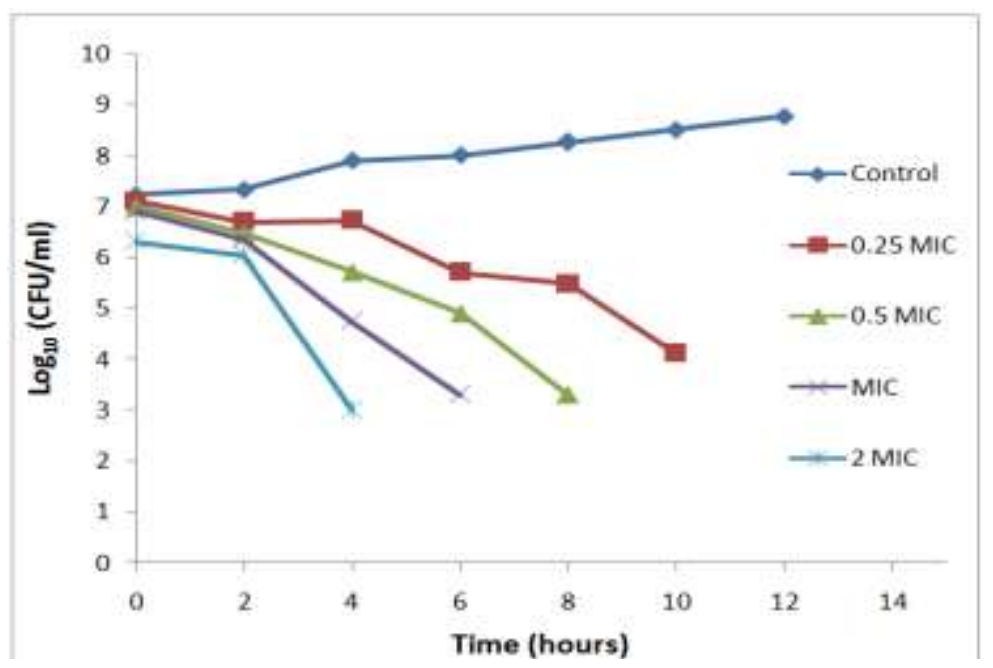

Fig. 2. The time kill curve of $K$. pneumonia isolate no. 3 treated with MEO

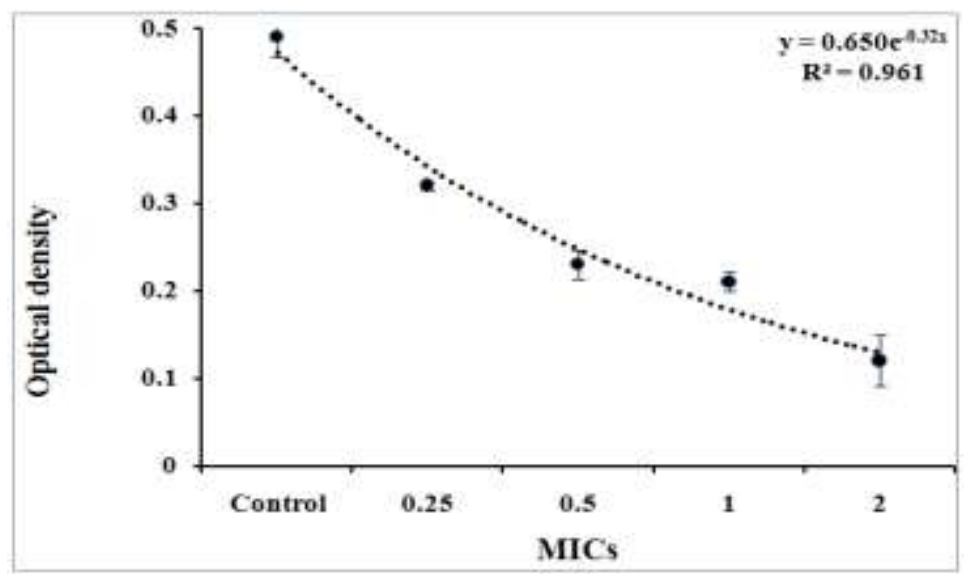

Fig. 3. Effect of different concentrations $\mathrm{MEO}$ on cell membrane permeability of $K 3$
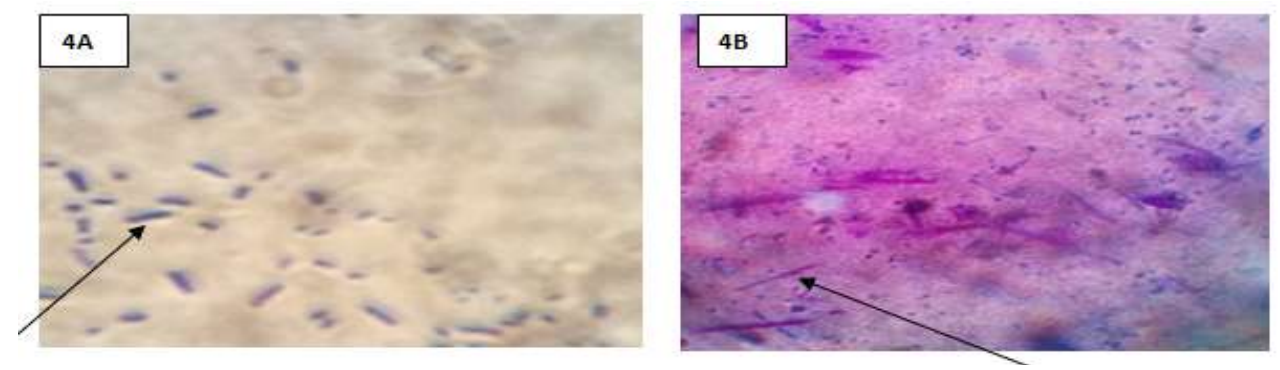

Fig. 4. Visualization of capsule expression under light microscopy of $\mathrm{K}_{3}$; A) control cells $\mathrm{B}$ ) cells exposed to MEO at MIC 
DNA fragmentation is a technique that can detect the ability of specific individual compound or mixture of compounds to degrade an intact molecule of DNA. The obtained results in figure 5 revealed that the control sample (bacterial cells without MEO) reflected better intensity and integrity of DNA band (lane 1), a gradual degradation with the addition of $1 / 2$ MIC and MIC of MEO was noticed (lane 2, 3), whereas a high DNA degradation was observed when the bacterial cells were incubated with $2 \mathrm{MIC}$ of the tested essential oil (lane 4).

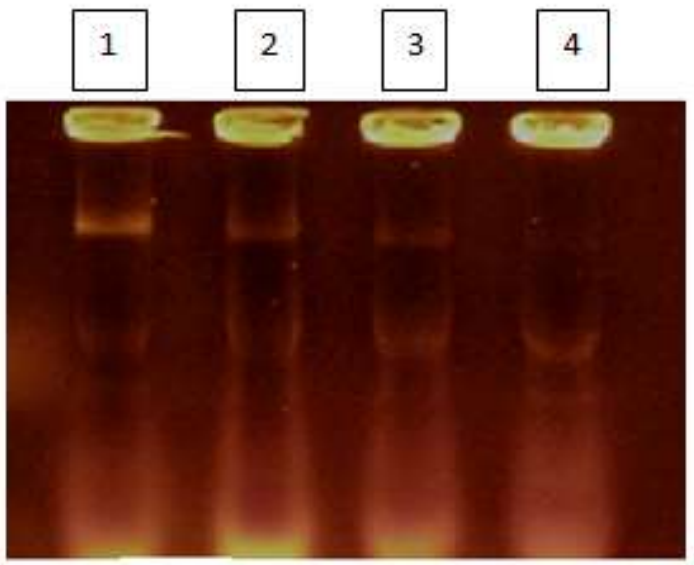

Fig. 5. Agarose gel analysis of genomic DNA isolated from K. pneumoniae. Lane 1: DNA of control cells; Lane 2: DNA of K. pneumoniae incubated with 1/2 MIC; 3: DNA of bacterial cells incubated with MIC; 4: DNA of cells incubated with 2 MIC.

\section{Discussion}

The world has been facing a big challenge of antimicrobial resistance that affects the efforts undertaken to prevent and control infectious diseases caused by bacteria. ${ }^{25}$ The wide use of antibiotics in the treatment of bacterial infections has led to the emergence and spread of resistant strains. The emergence of multiple drug resistant bacteria has become a major cause of failure of the treatment of infectious disease. ${ }^{\mathbf{2 6}}$ Results revealed that all isolates under this study were resistant to more than three antibiotics, where this property indicates that these Gram negative bacteria are multiple drug resistant (MDR). These results are in agreement with that reported by Wang et al. ${ }^{27}$ and Neu. ${ }^{28}$ where they proved that IPM is extremely useful antibacterial agent because of its great $B$-lactamase stability and high intrinsic activity against a broad range of bacteria. Other study conducted by Abou Zeid ${ }^{29}$ reported that, IPM is a broad-spectrum antibacterial agent, active against multiresistant bacteria including $K$. pneumoniae. As a result of the massive use of antibiotics in human therapy, bacteria have developed several resistance mechanisms such as target site modification, expression of efflux pumps of antibiotics, and metabolic inactivation which contribute to drug resistant. ${ }^{\mathbf{3 0 , 3 1}}$

Increase of infections based on antibiotic resistant microorganisms has to use new and natural antimicrobials. ${ }^{32}$ Plants have formed the basis of sophisticated traditional medicine system and natural products make excellent leads for new drug development. The World Health Organization (WHO) is encouraging, promoting and facilitating the effective use of herbal medicine in developing countries for health programs ${ }^{26}$. It could be concluded that MEO is more potent on MDR K. pneumoniae than the tested antibiotics and other tested essential oils. MEO exerted a bactericidal effect against the bacterial isolates under this study because the $\mathrm{MBC} / \mathrm{MIC}$ ratio values were lower than $1.2^{33}$

According to bibliographic data, there exist two main chemotypes of $O$. majorana EO: one consists mostly of monoterpene alcohols and the other of phenols. In the first chemotype, terpinen-4-ol, is either alone or together with other monoterpene alcohols such as cis- and trans-sabinene hydrate. It has been found to be the main volatile components. ${ }^{34}$ As for the second chemotype, the major compounds consisted mainly of thymol. ${ }^{35}$ and/or carvacrol. ${ }^{\mathbf{3 6}}$ Based on these data, it was found that EO of $O$. majorana grown in Egypt presents characteristics of the first chemotype. Edris et al. ${ }^{37}$ counted marjoram cultivated in Egypt to cis-sabinene hydrate/ terpinene-4-ol chemotype.

Kotan et al. $^{\mathbf{3 8}}$ reported that terpinen-4-ol, $\alpha$-terpineol and linalool exhibited a high antibacterial activity at a broad spectrum. The inhibitory action of marjoram is probably due to the action of the major compound terpinen -4-ol, which is believed to work by inhibiting oxidative respiration, inducing membrane deformation (dilatation) with consequent changes in membrane permeability. ${ }^{39}$ The leaves of the Origanum herb are rich in essential oil which confers its characteristic and fragrance. Several studies have shown that the essential oil of 
Origanum is composed of majority of constituents giving it the biological activities. The extraction product can vary in quality, quantity and composition according to climate, soil composition, geographical location, seasonal variation, plant organ, age and vegetative cycle stage, harvesting time. ${ }^{\mathbf{4 0}}$

Kill-time study was performed to gain a better insight on bacteriostatic or bactericidal effects of EOs. This study is very important especially when using drugs with bacteriostatic action considering that the dose for most effective treatment can be adjusted, thus avoiding the toxic effect to the patient. ${ }^{41}$ As demonstrated in this study, the increased concentration of MEO implies increase in its antimicrobial activity. Other authors (Goncalves et al. ${ }^{42}$ ) found that the treatment of $K$. pneumoniae with $2 \mathrm{MIC}$ of EO of Plectranthus amboinicus was enough to kill all the bacterial cells after $12 \mathrm{~h}$ of incubation compared to the control. Beside this observation, alternation in membrane permeability was detected by increasing crystal violet uptake when the bacteria were incubated with twice the MIC levels of MEO. The disruption of the cell membrane by essential oils may help in various vital processes such as energy conversion processes, nutrient processing, synthesis of structural macromolecules, and secretion of many growth regulators. ${ }^{43}$ MIC and 2MIC of MEO have a remarkable effectiveness against $K_{3}$ under study. Similar results were reported by Goncalves et al. ${ }^{\mathbf{4 2}}$ where he found that treatment of K. pneumoniae with 2MIC from EO of Plectranthus amboinicus caused significant change in the uptake of crystal violet (p $<0.01$ ). Also, Hammer et al. ${ }^{44}$ found that the treatment of Candida albicans with tea tree oil and its components at concentrations between 0.025 and $1.0 \%$ altered membrane permeability.

Klebsiella pneumoniae is a non motile enteric organism that forms large mucoid colonies, due to the presence of capsule. The capsule of $K$. pneumoniae consists of thick and dense bundles of fine fibres, which contribute to its high virulence capacity. ${ }^{43}$ In this study, when $K_{3}$ was investigated in the presence of MIC Of MEO, an alternation of its morphology besides reduction of capsule expression was detected. Svoboda $\&$ Hampson ${ }^{45}$ suggested that EOs can react by its lipophilic functions with the lipid parts of cell membrane where the biosynthetic enzymes for capsular polysaccharide are located. The present data are similar to those reported by Derakhshan et al. ${ }^{46}$, who found that exposure of K. pneumoniae ATCC 13883 to EO of Cuminium cyminum reduced the expression of capsular layer.

Genomic DNA fragmentation is the characteristic for cell death, unlike in eukaryotic cell, DNA fragmentation in microorganisms is rarely evaluated. The DNA fragments in MDR K. pneumoniae induced by MEO was observed using agarose gel electrophoresis. The results revealed that increasing the MEO concentration leads to increase in the fragmentation compared to untreated cells. Degradation of genomic DNA due to the activation of endonucleases is one of the early events of bacterial destruction. ${ }^{47}$ The authors also studied the ability of Glycosides and flavonoids compounds to induce the cleavage in whole cells, a marked DNA fragmentation was observed when pathogenic bacteria such as E.coli, Staphylococcus aureus and K. pneumoniae were treated with the glycoside and flavonoids extracts of Caesalpinia coriaria for 24 hours. Our results confirmed that some active constituents in MEO can interact with DNA of the bacteria causing its degradiation, this may play a role in intercalation or hydrogen bonding with the stacking of nucleic acid bases and this may explain the inhibitory action on DNA synthesis. ${ }^{48}$ When a cell singed under environmental stress, it stops, or at least, slows down most of its original functions, such as transport processes, DNA, RNA and protein synthesis. Although the main action of essential oils as antimicrobial agents seems to be centred in its activity on the cell membrane, this is not the only mechanism of action. Gustafson $\&$ Bowen $^{49}$ have previously reported the potential of essential oils to coagulate some cell constituents, probably by denaturation of proteins. Numerous studies have also reported the capacity of some phenolic and nonphenolic compounds of essential oils to interact with chemical groups of proteins and other biologically active molecules, such as RNA, DNA and enzymes. ${ }^{50}$

\section{Conclusion}

This study concluded the efficacy of MEO for the management of diseases caused by MDR K. pneumoniae isolates under low concentrations, which may be related to its adverse effects on cell membrane permeability, capsule production and DNA integrity. This will encourage efforts toward the development of novel antibacterial agents that could be better in terms of efficacy and safety.

\section{References}

[1]. Barik CS, Kanungo SK, Tripathy NK, Padhi M. The efficacy of herbs against Klebsiella pneumoniae with special reference to polyherbal formulation: An update. Pharma Science Monitor 2014; 5(3) Supl-1, Jul-Sep 2014.

[2]. Karen EB, Paul MD., Fionnuala McA. et al. Global gene expression in Staphylococcus aureus biofilms . J. Bacteriol. $2004 ; 186$ (14): 4665-84.

[3]. Lewis K. Persister cells and the riddle of biofilm survival. Biochemistry (Moscow). 2005; 70, 267-74.

[4]. Patel R. Biofilms and antimicrobial resistance. Clin. Orthop. Relat. Res. 2005; 41-47.

[5]. Nwankwo EOK, Abdulhadi S, Magagi A, et al. Methicillin resistant S. aureus (MRSA) and their antibiotic sensitivity pattern in Kano NIGERIA. Afr. J. Cln. Exper. Microbio1 2010; 1, (1): 129-136.

[6]. World Health Organization WHO 2014. (Antimicrobial resistance: Global report on surveillance).

[7]. Vashist H, Jindal A. Antimicrobial activities of medicinal plants. Review. Int. J. Res. Pharma Biomed.Sci. 2012; 3, 222- 30.

[8]. Bozin B, Mimica-Dukic N, Simin N, Anackov G. Characterization of the volatile composition of essential oils of some Lamiaceae spices and the antimicrobial and antioxidant activities of the entire oils. J. Agric. Food Chem. 2006; 54(5): 1822-1828.

[9]. Akthar MS, Degaga Azam B. Antimicrobial activity of essential oils extracted from medicinal plants against the pathogenic microorganisms: A review. Issues in Biological Sciences and Pharmaceutical Research 2014; 2 (1), pp. 001-007.

[10]. Bauer AW, Kirby WMM, Sherris JC et al. Antibiotic susceptibility testing by a standardized single disk method. Am J Clin Pathol. $1966 ; 45,493-496$. 
[11]. Clinical and Laboratory Standards Institute (CLSI). Performance Standards for Antimicrobial Susceptibility Testing Document Approved Standard M100-S20. PA, USA: Wayne; 2010.

[12]. Salie F, Eagles PFK, Leng HMJ. Preliminary antimicrobial screening of four South African Asteraceae species .J. Ethnopharmacol. 1996; 52: 23-27.

[13]. Bazaraa WA, Riyad YM, Abdel-Salam SM, et al. The antimicrobial activity of Millard reaction products in model and applied systems. Bull. Fac. Agric. Cairo Univ., 2005; 56:

[14]. Jayaprakasha GK, Selvi T, Sakariah KK. Antibacterial and antioxidant activities of grape (Vitisvinifera) seed extract. Food Research International. 2003; 36: 117-122.

[15]. Freeman DJ, Falkinern FR, Keane CT. New method for detecting slime producing by coagulase negative Staphylococci, J. Clin. Pathol. 1989; 42:872-74.

[16]. Christensen GD, Simpson AW, Younger JJ, et al. Adherence of coagulase negative staphylococci to plastic tissue culture plate: a quantitative model for the adherence of staphylococci to medical devices. J. Clin. Microbiol., 1985;22, 996-06.

[17]. Baldassarri L, Simpson AW, Donelli G et al. Variable fixation of staphylococcal slime by different histochemical fixatives, Eur. J. Clin. Microbiol., Infect.Dis. 1993;12: 866-68.

[18]. Klepser ME, Ernst EJ, Lewis RE, et al. Influence of test conditions on antifungal time-kill curve results: proposal for standardized method. Antimicrob. Agents Chemother. 1998; 42, 1207-12.

[19]. Devi KP, Nisha SA, Sakthivel R, et al. Eugenol (an essential oil of clove) acts as antibacterial agent against Salmonella typhi by disrupting the cellular membrane. Journal of Ethnopharmacology. 2010; 130: 107-15.

[20]. Finegold SM, EJ Barton. Bailey and Scott's diagnostic microbiology. St Lousis, M.O:Mosby. 1990.

[21]. Ahsan N, Paul N, Islam N, Akhand AA. Leaf Extract of Syzygiumcumini Shows Anti-Vibrio Activity Involving DNA Damage. Dhaka Univ J Pharm Sci. 2012; 11: 25-28.

[22]. Bollet C, Gevaudan MJ, de Lamballerie X, Zandotti C et al. A simple method for the isolation of chromosomal DNA from Gram positive or acid-fast bacteria. Nucleic Acids Research, 1991; Vol. 19, No. 81955.

[23]. Sendecor WG, Cochran GW. Statistical methods, $7^{\text {th }}$ ed, lowa state University, Ames, low, USA; 1980.

[24]. Krivoshein, Yu. 'Handbook on Microbiology Laboratory Diagnosis of infection diseases'. 36, Mir. Pub. Moscow; 1989.

[25]. Elibariki EK, Cecilia L, Musa C. Evaluation of Antibacterial Activity of Five Selected Medicinal Plants in Tanzania against Gram Negative Bacteria. European Journal of Medicinal Plants, 2016; 12(2): 1-7.

[26]. Ibrahim TA, Opawale BO, Oyinloye JMA. Antibacterial activity of herbal extracts against multi drug resistant strains of bacteria from clinical origin. Life Sci. Leaflets, 2011; 15, $490-498$.

[27]. Wang C, Galandra GB, Aziz MA et al. Efficacy and safety of imipenem/cilastatin: A review of world-wide clinical experience. Rev. Infect.Dis., 1985; 7: 528-36.

[28]. Neu HC. Overview of mechanisms of bacterial resistance . BIAGN. Microbiol. Inf. Dis., 1989; 19, 2045-50.

[29]. Abou Zeid AA, M.A. Shalaby, M.M. Abdel Aziz. Control of some multi-resistant bacteria infecting upper respiratory system using certain essential oils and plant extracts. Proceeding of fifth scientific environmental conference, Zagazig Univ., 2010; 87- 105.

[30]. Hooper DC. Emerging mechanisms of flouroquinolone resistance. Emerg. Infect. Dis. 2001; 7 (2): 337- 41.

[31]. Yala D, Merad AS, Mohamedi D, et al. Classification et mode d'action des antibiotiques.Me`decine de Magreb. 2001; 91, 5-12.

[32]. Keskin D , Toroglu S. Studies on antimicrobial activities of solvent extracts of different spices. J. Environ. Biol. 2011; 32: 251-256.

[33]. Humberto H, Lara V, Ayala-Nunez NV et al. Bactericidal effect of silver nanoparticles against multi-drug- resistant bacteria World J. of Microbiol. and Biotechnol., 2010; 26, 615-621.

[34]. Sarer E, Scheffer JJC, Svedsen AB. Monoterpenes in the essential oil of Origanum majorana. J. Med. Plant Res. Planta Med. 1982; 46, 236-239.

[35]. Jolivet J, Rey P, Boussarie MF. Differenciation de quelques huiles essentielles presentant une constitution voisine. II. Essence de marjolaine. Plantes Med. Phytother. 1971; 5, 199-208.

[36]. Baser KHC, Kirimer N, Tumen G. Composition of the essential oil of Origanum majorana L. from Turkey. J. Essent. Oil Res. 1993; 5, 577-579.

[37]. Edris AE, Shalaby A, Fadel H M. Effect of organic agriculture practices on the volatile aroma components of some essential oil plants growing in Egypt II: sweet Marjoram (Origanum majorana L.) essential oil. Flavour Frag. J. 2003; 18, 345-351.

[38]. Kotan R, Kordalic S, Cakird A. Screening of antibacterial activities of twenty one oxygenated monoterpenes. Z. Naturforsch. 2007; $62,507-517$.

[39]. Cox SD, Mann JL, Bell HC et al. The mode of antimicrobial action of the essential oils of Melaleuca alternifolia (tea tree oil). J.Appl. Mirobiol. 2000; 88, 170-75.

[40]. Al-Akhal F, El-Ouali L, EZ Z Y, et al. Chemical composition and Larvicidal activity of Culex pipiens (Diptera Culicidae) of essential oil Origanum majorana (Lamiaceae) cultivated in Morocco. Asian Pas. J. Trop. Biomed. 2014; 4 (issue 9): 746-750.

[41]. Guerra SQF, Medes MJ, Araujo de Oliveira W, et al. Chemical composition and antimicrobial activity of Cinnamomum zeylanicum Blue Essential oil on multi-drug resistant Acinetbacter spp. Biofar. 2012; 8 (1): 62-70.

[42]. Goncalves TB, Braga MA, De Oliveira FFM, et al. Effect of subinhibitory and inhibitory concentrations of Plectranthus ambonicus Lour). Spreng essential oil Klebsiella pneumoniae. phytomedicine 2012;19, 962-68.

[43]. Oussalah M, Caillet S, Lacroix M. Mechanism of action of Spanish oregano, Chinese cinnamon, and savory essential oils against cell membranes and walls of Escherichia coli O157:H7 and Listeria monocytogenes. J. Food Prot. 2006; 69 (5): 1046-1055.

[44]. Hammer KA, Carson CF, Riely TV. Antifungal effects of Melaleuca alternifolia (tea tree) oil and its components on Candida albicans , Candida glabrata and Saccharomyces cerevisiae. J. of Antimicrob. Chemother. 2004; 53, 1081-85.

[45]. Svoboda P, Hampson JB. Bioactivity of essential oils of selected temperate aromatic plants: Antibacterial, antioxidant, antiinfilammatory and other related pharmacological activities. Ayr, UK: Scottish Agriculturral College; Available from : http:/ www. ienica .net/specchemseminar / svoboda.pdf; 1999.

[46]. Derakhshan S, Sattari M, Bigdeli M. Effect of subinhibitory concentration of cumin (cuminum cumminum L.) seed essential oil and alcoholic extract on the morphology, capsule expression and urease activity of Klebsiella pneumoniae. Inter . J. of Antimicrob. Agents 2008; 32, 432-36.

[47]. Anandhi D, Srinivasan PT, Praveen G, Kumar, Jagatheesh S. DNA fragmentation induced by the glycosides and flavonoids from C.coriaria. Int.J.Curr.Microbiol. App.Sci. 2014; 3(12): 666-673.

[48]. Mori A, Nishino C, Enoki N, Tawata S. Antibacterial activity and mode of action of plant flavonoids against Proteus vulgaris and Staphylococcus aureus. Phytochemistry, 1987; 26:2231 4.

[49]. Gustafson RH, Bowen RE. Antibiotic use in animal agriculture. J. Appl. Microbiol. 1997; 83, 531 - 541 .

[50]. Calsamiglia S, Busquet M, Cardozo PW, et al. Invited Review: Essential Oils as Modifiers of Rumen Microbial Fermentation. J. Dairy Sci. 2007; 90, 2580-2595. 